\title{
Simulation of X-Ray Plane Using Visual Basic Applications
}

\author{
Gunawan Osman ${ }^{1}$, Lukman Medriavin Silalahi ${ }^{2 *}$, Muhammad Agung \\ Juhardi $^{1}$, Setiyo Budiyanto ${ }^{2}$, Hendrana Tjahjadi ${ }^{3}$, Agus Dendi Rochendi \\ ${ }^{I}$ Department of Electromedic Engineering Universitas Mohammad Husni Thamrin, Jl. Salemba Tengah, \\ Senen, Jakarta 10440 \\ ${ }^{2}$ Department of Electrical Engineering Universitas Mercu Buana, Jl. Raya Meruya Selatan, Jakarta \\ ${ }^{3}$ Department of Armament Engineering Universitas Pertahanan Indonesia \\ ${ }^{4}$ Kawasan IPSC Sentul, Sukahati, Jawa Barat 16810 Department of Oceanographic physics, Lembaga Ilmu \\ Pengetahuan Indonesia Jl. Pasir Putih I, Ancol Timur, Jakarta 14430 \\ *Corresponding author. Email: lukman.medriavin@mercubuana.ac.id
}

\begin{abstract}
$\mathrm{X}$-Ray Plane is a tool that works using X-ray radiation for fluoroscopy and radiographic purposes. This beam is emitted from the tube directed at the body part and will be captured by the film, so that an image of the illuminated part of the body will be formed. X-rays are produced in a vacuum glass tube and generally consist of a source for producing electrons, an energy source for accelerating electrons, cross-free electrons, a focusing of former electrons, and a material to stop electrons. The purpose of this research was to produce a simulated prototype X-Ray Plane using Visual Basic applications. The proposed research method is System Development Life Cycle (SDLC), which is a process of creating and changing systems and models / patterns taken to develop software systems, which consists of stages including planning, analysis, design, implementation, and testing. The results of this research showed that high voltage setting $90 \mathrm{kV}$, current setting 100 $\mathrm{mA}$, and exposure timer 0.24 . The 3 parameters are in accordance with the hardware that has been set and for the thickness of the object still chooses $16 \mathrm{Cm}$, so the result of the image is too over because the settings on $\mathrm{kV}, \mathrm{mA}$, and expose time is too large for a thickness of $16 \mathrm{Cm}$.
\end{abstract}

Keywords: X-Ray, Fluoroscopy, Radio Graphic, Visual Basic

\section{INTRODUCTION}

$\mathrm{X}$-Ray Plane is a tool that works using X-ray radiation for fluoroscopy and radiographic purposes. In a vacuum glass tube containing cathode filaments and anodes and is built from multiple sources to produce electrons, cross-free electrons, ex-electron focusing and materials to stop electrons from producing the product X-rays. This means that if there is a heating of the filament will result in electrons coming out and if the cathode and anode are given a high potential difference, the electrons will move quickly towards the anode. With the rapid movement of these electrons, there will be a collision between the electron and the anode, resulting in the emission of X-ray radiation [1]. At the time the device will be operated, it is necessary to make ar- rangements on the parameters, including high voltage $(\mathrm{kV})$, current $(\mathrm{mA})$ and exposure time. The control system for these three parameters must have high accuracy, so that the x-rays produced meet medical standards and do not exceed the permitted tolerance limits. In conventional $\mathrm{x}$-ray aircraft the control system still uses analog system that is still using rotary switch as selector. The way analog systems work is still low in accuracy and less efficient in the use of cables. [2] X-ray aircraft also have high radiation. Radiation doses can affect humans, animals, plants and all kinds of living things. Optimization of radiation doses is essential for the quality and quantity of $\mathrm{x}$-ray equipment. Widespread use of $\mathrm{X}$-rays in patient diagnosis and management leads to increased radiation exposure. [2] An effective dose is a dose of a size designed to represent the overall 
biological effects that can be damaging from radiation exposure. The dose is calculated based on the weight of the concentration of energy stored in each organ from radiation exposure with the use of parameters that reflect the type of radiation and potential radiation-related mutagenic changes in each organ in the reference subject. [3] Excessively high doses of $\mathrm{x}$-ray radiation will cause the patient to receive unnecessary radiation that can lead to ionization of soft tissues, organs and fluids in the human body that can cause cell damage and cause cancer. The resulting image will also be darker especially on conventional x-ray aircraft. [4]

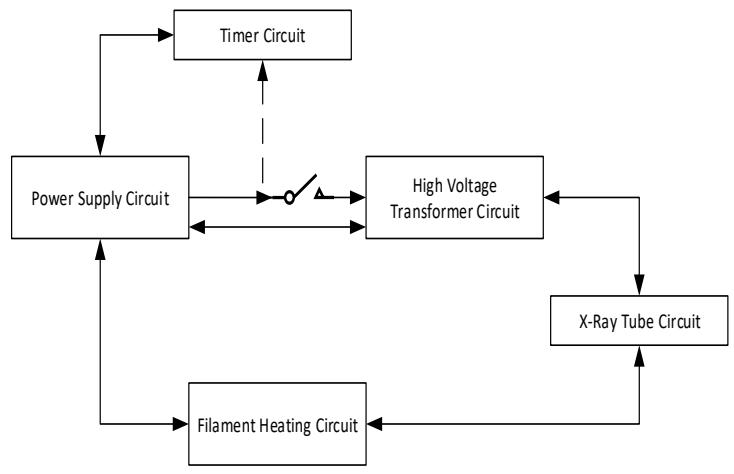

Figure 1. Conventional X-ray plane diagram block

Figure 1 shows diagram blocks divided into several constituent parts, including power supply circuit, Timer Circuit, HVT Circuit, X Ray Tube Series, and Filament Heating Circuit. [5-7]

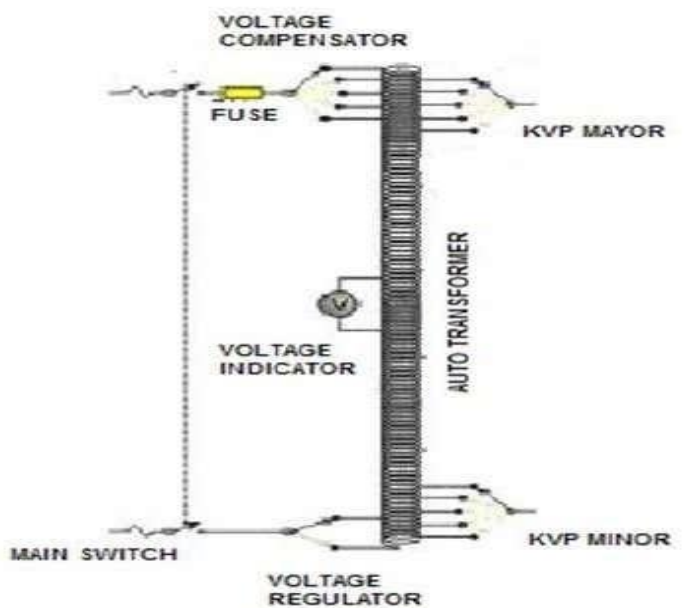

Figure 2. Power supply circuit

Figure 2 shows a simple series of power supply consisting of:
1. Switch that serves to connect pln supply listik with roentgen aircraft.

2. Fuse that serves for safety

3. Voltage Compensator that serves to compensate the voltage value required by the aircraft in case of decrease in the supply of PLN If the voltage rises we must increase the number of primary coils by rotating the selector voltage compensator and if the voltage drops we must reduce the number of primary coils by rotating the selector voltage compensator so that a comparison of the transformation between the voltage and the number of primary coils with the voltage and the number of secondary coils ad alah fixed thus obtained the voltage value on each coil will remain.

Figure 3 shows a series of filament heater blocks consisting of several circuits, including voltage stabilizer circuits, Space Charge Compensators, current controllers, Stand by Resistance, filament limiters, transformer filaments, and filament x-ray tubes.

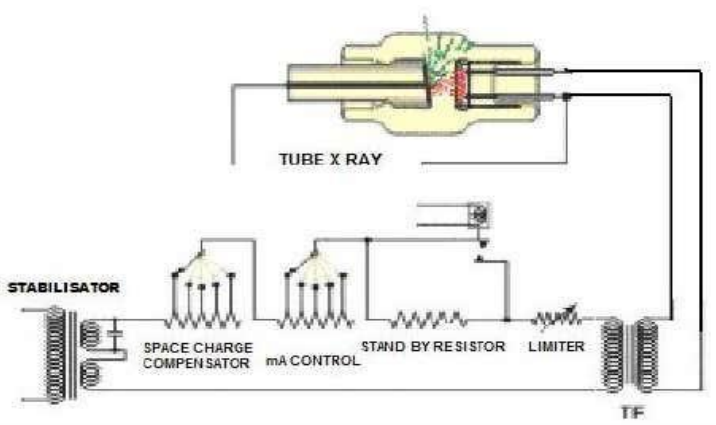

Figure 3. Filament heating circuit

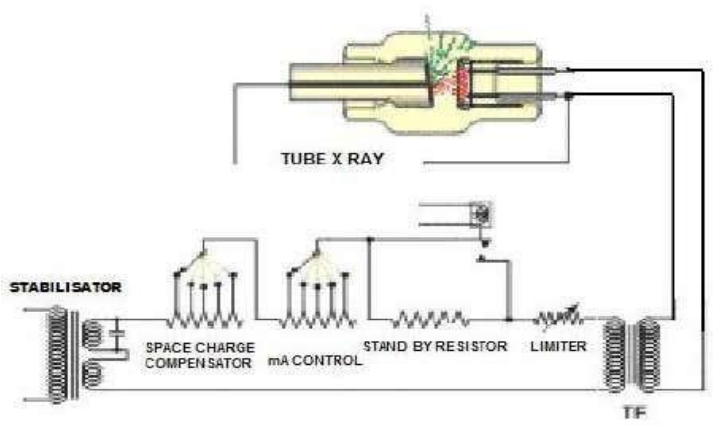

Figure 4. High voltage transformer circuit

Figure 4 indicates a series of high voltage transformers that serve to provide a potential difference between anodes and cathodes where anodes must always get positive polarity and the cathode must always get negative polarity so that the free electrons around the cathode can be drawn to the anode. 
Figure 5 shows a series of X-ray tubes designed from diode tubes/vacuum tubes consisting of two electrodes, namely anodes and cathodes. This tube is also where the X-ray is formed. There are several types of X-ray tubes on X-ray aircraft, including:

1. Aircraft with 1 unit of $x$ ray tube over table for single shooting is called "X-ray Aircraft 1 examination"

2. X-ray aircraft that have $x$ ray tube over table and under table called 2 Examination. [7]

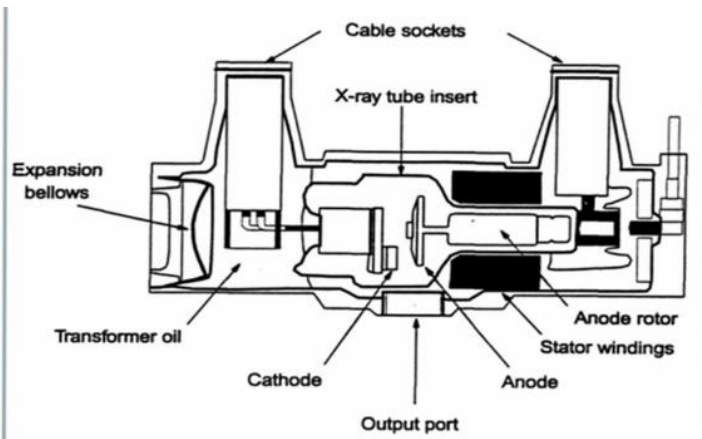

Figure 5. X-ray tube circuit

X-rays (X-rays) are electromagnetic waves, with wavelengths that tend to be very short, but have enormous energy. These X-rays have very high translucency, and have the ability to ionize atoms from the material they pass through, and then make them a form of electromagnetic radiation. [8-9]

Visual Basic is a windows-based programming language. Today, Visual Basic is one of the best programming languages. Visual Basic is a development of Basic. Basic (Beginner's All-purpose Symbolic Instruction Code) is an "ancient" programming language that is the beginning of other high-level programming languages. Basic was designed in the 1950 s and is intended to be used by novice programmers. Usually Basic is taught to high school students who are new to computers, and used for the development of a light and fun "fast food" program. [8-9] Microsoft Visual Basic is a programming language that offers a visual Integrated Development Environment (IDE) for creating software programs based on the Microsoft Windows operating system by using a programming model (COM). [8-9]

\section{RESEARCH METHOD}

System Development Life Cycle (SDLC) is a proposed research method in the process of designing systems, models, and methods. The output of the
SDLC method taken is to produce a software system, which corresponds to the stages that start from planning, analysis, design, implementation, and testing. Table 1 materials and tools used in this research as components of the prototype design builder.

Table 1. Material and tools.

\begin{tabular}{|c|c|c|c|c|c|}
\hline \multicolumn{3}{|c|}{ Material } & \multicolumn{3}{c|}{ Tools } \\
\hline No & Name & $\begin{array}{c}\text { Amou } \\
\text { nt }\end{array}$ & No & Name & $\begin{array}{c}\text { Amou } \\
\mathrm{nt}\end{array}$ \\
\hline 1 & $\begin{array}{c}\text { Arduino } \\
\text { Uno }\end{array}$ & 1 & 1 & $\begin{array}{c}\text { Sol- } \\
\text { der }\end{array}$ & 1 \\
\hline 2 & $\begin{array}{c}\text { Rotary } \\
\text { En- } \\
\text { coder }\end{array}$ & 1 & 2 & $\begin{array}{c}\text { Tin } \\
\text { Suc- } \\
\text { tion }\end{array}$ & 1 \\
\hline 3 & $\begin{array}{c}\text { LCD } \\
\text { 20x4 }\end{array}$ & 1 & 3 & $\begin{array}{c}\text { Scis- } \\
\text { sor }\end{array}$ & 1 \\
\hline 4 & $\begin{array}{c}\text { Push } \\
\text { Button }\end{array}$ & 1 & 4 & $\begin{array}{c}\text { Tang } \\
\text { Peel }\end{array}$ & 1 \\
\hline 5 & PCB & 1 & & & \\
\hline 7 & $\begin{array}{c}\text { Jumper } \\
\text { Cable }\end{array}$ & 20 & & & \\
\hline
\end{tabular}

Figure 6 show the block diagram system designed, the working principle of this prototype is on rotary encoder first have to setup parameters Voltage $(\mathrm{kV})$, Current $(\mathrm{mA})$, Expose Time $(\mathrm{S})$, then the data is sent to the arduino to be processed and processed, and outside in the form of pushbutton as a expose button, after the pushbutton is pressed then arduino will process the data and displayed in the basic visual application.

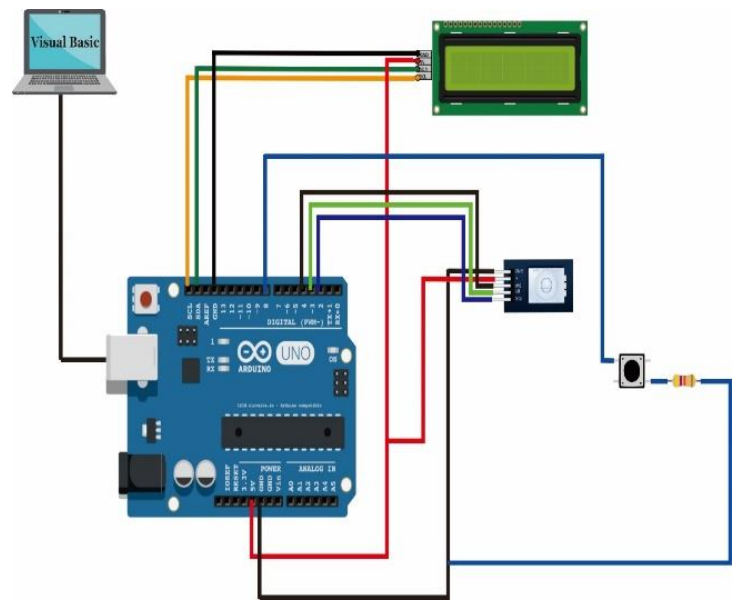

Figure 6. Wiring diagram. 
As well as for wiring diagrams can be seen in Figure 7.
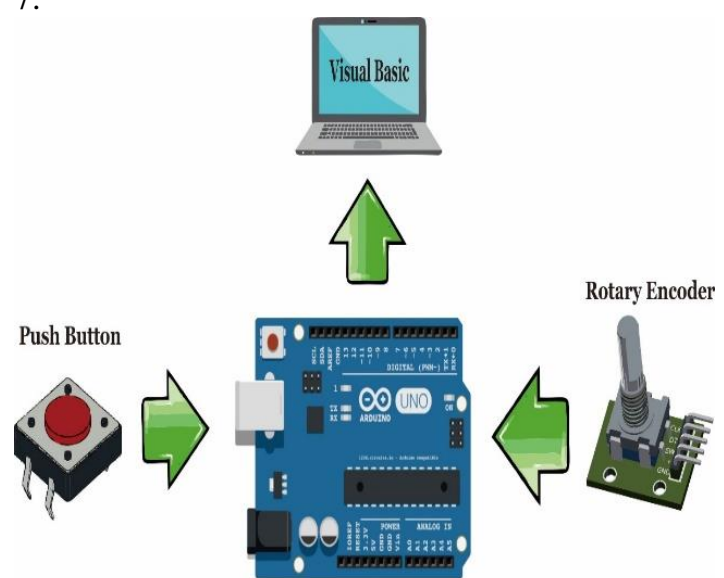

Figure 7. Block diagram.

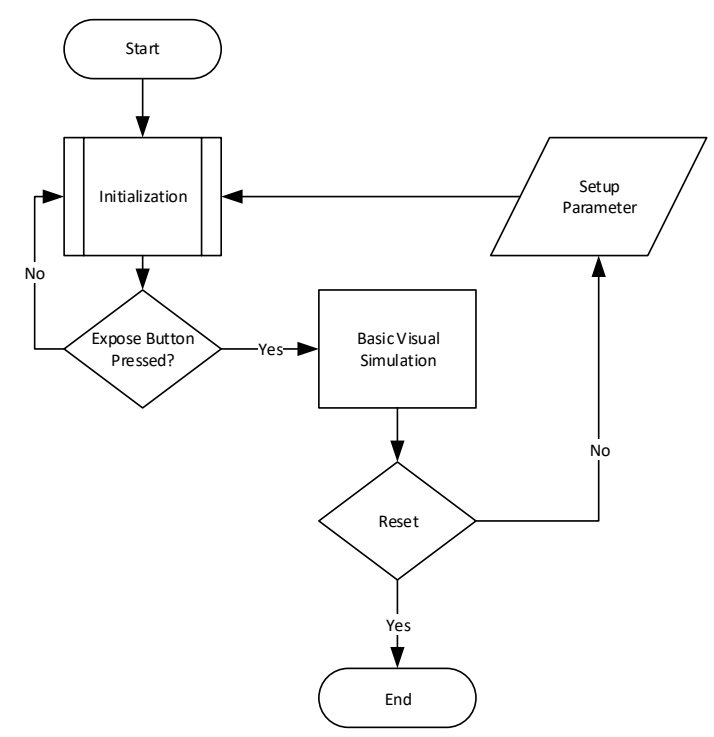

Figure 8. Flowchart design.

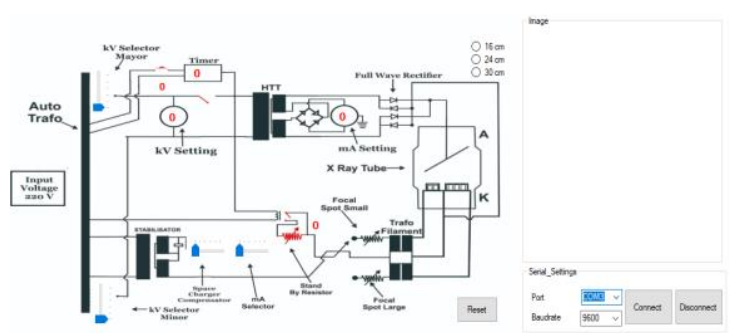

Figure 9. Visual Basic display.

Flowchart system can be seen in Figure 8. starting from the moment the system is run then there will be the initialization process of the program in Arduino, the first step is the parameters Voltage $(\mathrm{kV})$,
Current (mA), Expose Time (S), after that press the exposé button, if "yes" then the microcontroller will send data to the Visual Basic application and will display the image (Figure 9), after which if the reset button is pressed then the display will return to the original. If "no" then the process is complete.

\section{RESULTS AND DISCUSSION}

Figure 10 shows the results of hardware design that has been successfully assembled and when the application is run using visual basic successfully connected then do the process of setting parameters on the hardware. After that press the expose button then the display will change in expose mode and the circuit will follow the settings that have been set on the hardware as shown in Figure 11 - Figure 13.

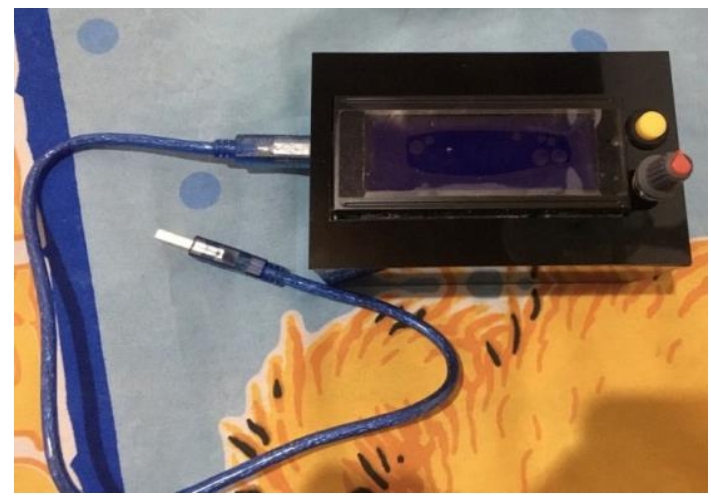

Figure 10. Prototype design results.

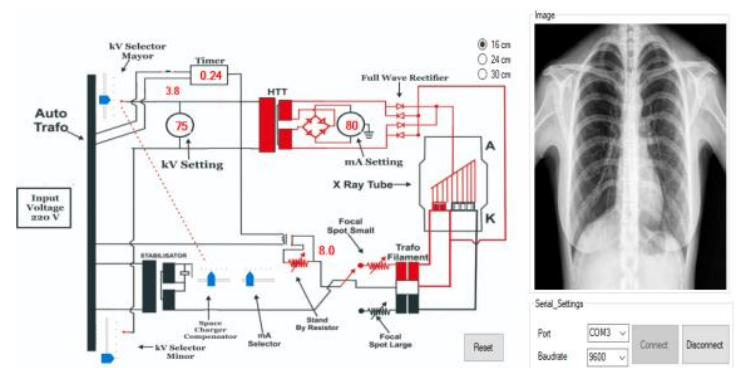

Figure 11. Display when the program is run at an object thickness of $16 \mathrm{~cm}$.

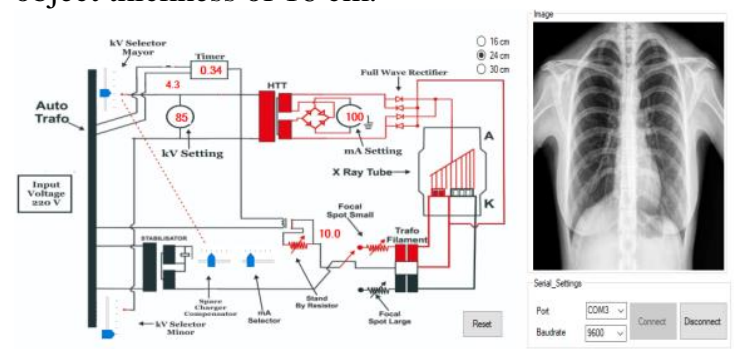

Figure 12. Display when the program is run at an object thickness of $24 \mathrm{~cm}$. 
Table 2. Data analysis

\begin{tabular}{|c|c|c|c|c|c|}
\hline No & High Voltage $(\mathrm{kV})$ & Current $(\mathrm{mA})$ & Expose Time (S) & Object Thickness $(\mathrm{Cm})$ & Result \\
\hline 1 & 75 & 80 & 0.24 & 16 & Clear \\
\hline 2 & 85 & 100 & 0.34 & 24 & Result Un-Clear \\
\hline 3 & 120 & 140 & 0.45 & 30 & $\begin{array}{c}\text { expose time is get- } \\
\text { ting longer because } \\
\text { the thickness of the } \\
\text { object becomes } \\
\text { thicker }\end{array}$ \\
\hline
\end{tabular}

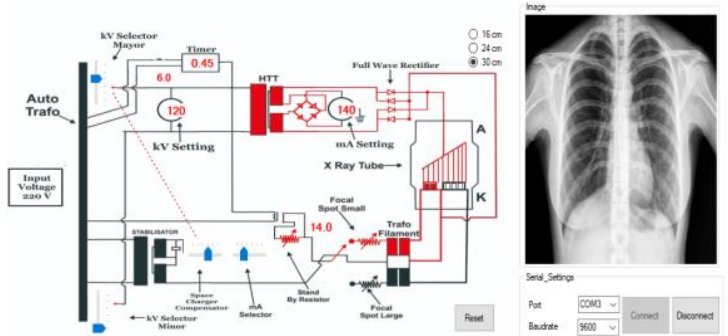

Figure 13. Display when the program is run at an object thickness of $30 \mathrm{~cm}$.

Based on Figure 11 - Figure 13 can be analyzed contained in Table 2.

\section{CONCLUSION}

The conclusion of this research can be stated that the prototype that has been designed has worked optimally and found that the higher the thickness of the object, the higher the exposure time required on the X-Ray plane simulation prototype.

\section{ACKNOWLEDGMENT}

The first special thanks to Universitas Mohammad Husni Thamrin which has supported in domestic collaborative research and the second to Universitas Mercu Buana, for his assistance and cooperation during this research. Hopefully there will always be papers with in future research.

\section{REFERENCES}

[1] Darwish DA, Abul-Nasr KT, El-Khayatt AM. The assessment of natural radioactivity and its associated radiological hazards and dose parameters in granite samples from South Sinai, Egypt. Journal of Radiation Research and Applied Sciences. 2015 Jan 1;8(1):17-25.

[2] Gholami M, Nemati F, Karami V. The evaluation of conventional X-ray exposure parameters including tube voltage and exposure time in private and governmental hospitals of Lorestan Province, Iran. Iranian Journal of Medical Physics. 2015 Jun $1 ; 12(2): 85-92$.
[3] Avinash S, Manjunath K, Kumar SS. An improved image processing analysis for the detection of lung cancer using Gabor filters and watershed segmentation technique. In2016 International Conference on Inventive Computation Technologies (ICICT) 2016 Aug 26 (Vol. 3, pp. 1-6). IEEE.

[4] Fajrin HR, Rahmat Z, Sukwono D. Kilovolt peak meter design as a calibrator of X-ray machine. International Journal of Electrical \& Computer Engineering (2088-8708). 2019 Aug 1;9(4).

[5] Gholami M, Nemati F, Karami V. The evaluation of conventional X-ray exposure parameters including tube voltage and exposure time in private and governmental hospitals of Lorestan Province, Iran. Iranian Journal of Medical Physics. 2015 Jun $1 ; 12(2): 85-92$.

[6] Taha MT, Al-Ghorabie FH, Kutbi RA, Saib WK. Assessment of entrance skin doses for patients undergoing diagnostic X-ray examinations in King Abdullah Medical City, Makkah, KSA. Journal of Radiation Research and Applied Sciences. 2015 Jan 1;8(1):100-3.

[7] Silaban FA, Budiyanto S, Raharja WK. Stepper motor movement design based on FPGA. International Journal of Electrical and Computer Engineering. 2020 Feb 1;10(1):151.

[8] Ferdana N, Adriansyah A, Budiyanto S, Andika J. Design of a telemedicine robot using behavior-based control architecture. InAIP Conference Proceedings 2020 Apr 13 (Vol. 2217, No. 1, p. 030092). AIP Publishing LLC.

[9] Adriansyah A, Ferdana N, Budiyanto S, Andika J. Design of Telemedicine Robot using Behavior-based Control Architecture with Two-Step Fuzzy Logic Optimization.

[10] Ramadhan, E., Firdausi, A., \& Budiyanto, S. (2017, November). Design and analysis QoS VoIP using routing Border Gateway Protocol (BGP). In 2017 International Conference on Broadband Communication, Wireless Sensors and Powering (BCWSP) (pp. 1-4). IEEE. 
[11] Silaban, F. A., Budiyanto, S., \& Raharja, W. K. (2020). Stepper motor movement design based on FPGA. International Journal of Electrical and Computer Engineering, 10(1), 151.

[12] Asvial M, Budiyanto S, Gunawan D. An intelligent load balancing and offloading in $3 \mathrm{G}-\mathrm{WiFi}$ offload network using hybrid and distance vector algorithm. In2014 IEEE Symposium on Wireless Technology and Applications (ISWTA) 2014 Dec 9 (pp. 3640). IEEE.

[13] Budiyanto S, Nugroho A, Nugraha B, Sirait F. IP over Radio: a Performance Evaluation for IoT System with Various Data Transmission Technique.

[14] Budiyanto S, Machsuni AH. LTE Implementation Model with Combination Carrier Aggregation Based on Area Demographics. In2020 2nd International Conference on Broadband Communications, Wireless Sensors and Powering (BCWSP) 2020 Sep 28 (pp. 123-128). IEEE.

[15] Budiyanto S, Al Hakim E. Feasibility Analysis the Implementation of the Dual Spectrum Licensed and Unlicensed Enhanced License Assisted Access (ELAA) on LTE Networks with the Techno-Economic Method. In2020 2nd International Conference on Broadband Communications, Wireless Sensors and Powering (BCWSP) 2020 Sep 28 (pp. 129134). IEEE.Falguera, V., Quintero, J.P., Jiménez, A., Muñoz, J.A., Ibarz, A. 'Edible films and coatings: structures, active functions and trends in their use". Trends Food Sci. Technol. 22, 292-303. (2011). 